\title{
PERAN PEREMPUAN DALAM STRUKTUR PEMERINTAHAN GAMPONG (STUDI GAMPONG BLANG KECAMATAN SYAMTALIRA ARON KABUPATEN ACEH UTARA)
}

\author{
Cut Laely, Murniati ${ }^{1)}$ \\ ${ }^{1}$ Program Studi Administrasi Publik FISIP Universitas Malikussaleh, murniati@unimal.ac.id
}

\section{ABSTRACT}

The Role of Women in village is the most important factor in development of village, but in Blang Village, Syamtalira Aron, North Aceh Regency, there is no role of women in the village governance structure. This is due to the fact that there are no opportunities for women to play an active role in village governance and cultural culture that opposes women to play a role in village governance. This study aims to determine the cause of the absence of women's role in the village government structure and determine the efforts that can be made for women to be able to play an active role in governance structure of village. Researchers used qualitative methods and data collection techniques through initial observation and direct interviews. The results of the study were the absence of an active role among women caused by the limited space for women to play an active role in the village government structure. Distrust of women so that women are placed in daily activities that generally have been carried out routinely by the community. Many factors cause limited space for women in Blang Village, namely factors of community organization, factors of power, factors of public and private, factors patriarchal ideological, and the most fundamental, culture that cause the role active of women can not be accepted at the community in the village government structure.

Keywords: Role, Women, Government, Village.

\begin{abstract}
ABSTRAK
Peran perempuan dibutuhkan dalam pembanggunan gampong, namun di Gampong Blang Kecamatan Syamtalira Aron Kabupaten Aceh Utara tidak terdapat peran perempuan dalam struktur pemerintahan gampong. Hal tersebut disebabkan oleh faktor tidak tersedianya peluang bagi kaum perempuan untuk berperan aktif dalam pemerintahan gampong serta kultur budaya yang menentang kaum perempuan untuk berperan di pemerintahan gampong. Penelitian ini bertujuan untuk mengetahui penyebab tidak optimalnya peran perempuan di struktur pemerintahan gampong dan mengetahui upaya yang dapat dilakukan agar perempuan dapat berperan aktif dalam struktur pemerintahan gampong. Peneliti menggunakan metode kualitatif dan teknik pengumpulan data melalui observasi dan wawancara langsung. Hasil penelitian adalah tidak adanya peran aktif dari kalangan perempuan karena disebabkan masih ada keterbatasan ruang gerak bagi kaum perempuan untuk ikut berperan aktif dalam struktur pemerintahan gampong dan ketidakpercayaan terhadap perempuan sehingga menjadikan perempuan hanya ditempatkan pada kegiatan sehari-hari yang umumnya telah dilakukan secara rutin oleh masyarakat. Banyak faktor penyebab terbatasnya ruang gerak bagi perempuan di Gampong Blang, yaitu faktor organisasi masyarakat, faktor kekuasaan, faktor ruang publik dan privat, faktor ideologi patriaki, serta yang paling mendasar adalah faktor budaya patriarki masyarakat Gampong Blang yang menyebabkan peran aktif perempuan tidak dapat diterima dalam struktur pemerintahan gampong.
\end{abstract}

Kata Kunci: Peran, Perempuan, Pemerintahan, Gampong. 


\section{PENDAHULUAN}

Keterlibatan perempuan menjadi syarat mutlak dalam upaya mewujudkan pembangunan yang berkeadilan. Negara senantiasa dituntut memfasilitasi peranan penuh dari kaum perempuan dalam segala bidang kehidupan. Dalam konteks ini dapat diartikan bahwa tidak ada perbedaan antara laki-laki dan perempuan untuk ikutserta berpatisipasi dalam mensukseskan programprogram pembangunan secara profesional dan hal ini dijamin oleh Konstitusi. Namun kenyataannya posisi dan peran perempuan dalam pembangunan masih termarginalkan hingga saat ini (Fakih, 2004).

Pentingnya peran perempuan juga ditekankan dalam Undang-Undang Nomor 6 Tahun 2014 tentang Desa. Berdasarkan peraturan tersebut, perempuan menjadi unsur masyarakat yang tidak boleh diabaikan keterlibatannya. Di Aceh sendiri peran aktif perempuan telah diatur oleh Qanun Nomor 6 Tahun 2009 tentang Pemberdayaan dan Perlindungan Perempuan. Pasal 14 ayat (1) menyatakan: "Pemerintah Aceh dan Pemerintah Kabupaten/Kota serta lembaga lainnya wajib memberikan kesempatan seluas-luasnya kepada perempuan untuk menduduki berbagai jabatan pada semua tingkatan pekerjaan secara profesional dan proporsional”.

Idealitas tersebut berbeda dengan realitas yang ditemui di Gampong Blang Kecamatan Syamtalira Aron Kabupaten Aceh Utara, dimana keterwakilan perempuan berperan aktif dalam struktur pemerintahan gampong dan pelibatan perempuan dalam proses kegiatan di gampong masih minim. Hal ini terlihat jelas saat diadakannya Musrembang Gampong, dimana kalangan perempuan yang hadir hanya terdiri dari satu atau dua orang saja untuk mewakili suara perempuan.

Selanjutnya peneliti melakukan wawancara terhadap Anwar Aziz selaku Geucik Gampong Blang. Menurutnya, kaum perempuan tidak dikehendaki untuk memegang kedudukan di pemerintahan gampong yang dilegitimasi melalui adat istiadat dan kultur budaya. Perempuan diharuskan untuk mengurus kemajuan rumah tangga mereka masing-masing, mengingat bahwa perencanaan pembangunan gampong dan musrembang sering diadakan pada malam hari, sehingga peran dan partisipasi perempuan terbatas untuk ikutserta dalam pembangunan gampong. Di samping itu, aturan gampong yang tidak membolehkan kaum perempuan untuk berada di luar rumah pada malam hari ikut menghambat keterlibatan kaum perempuan. Akhirnya kaum laki-laki menjadi aktor tunggal dan memegang kendali dalam pembangunan gampong (wawancara 22/12/2018).

Minimnya keterlibatan perempuan dalam struktur dan kegiatan pemerintahan gampong didukung oleh sebuah kesadaran tentang kurang pentingnya masalah gender sehingga tidak pernah ditanggapi secara serius oleh penguasa yang didominasi kaum laki-laki maupun masyarakat dari 
kaum perempuan sendiri. Pandangan hidup dan budaya patriarki ini menimbulkan kesenjangan peran dan berbagai bentuk ketimpangan yang lain. Pada akhirnya daya tawar perempuan selalu berada dalam posisi lemah. Rendahnya keterwakilan perempuan secara kuantitatif dalam lembaga pemerintahan merugikan kaum perempuan. Dalam situasi demikian mendorong lahirnya berbagai macam tuntutan kesetaraan hak dan kewajiban di berbagai belahan dunia.

\section{Peran Perempuan dalam Teori Feminis}

Dalam teori feminis wanita ditempatkan sebagai pusat sistem gagasan (Ritzer, 2008: Fitri, 2009). Dengan demikian, pengalaman, sudut pandang, dan aksi ditujukan pada kepentingan kaum perempuan untuk dapat setara dengan kaum laki-laki. Feminisme mempertanyakan ketimpangan peran gender. Peran adalah aspek dinamis dari sekumpulan hak dan kewajiban (Sunarto, 2004). Konsep peran terkait dengan status (Soekanto, 2006), fungsi (Nasution, 2002), pengaruh (Moekijat, 2001), dan harapan sosial (Berry, 2003). Feminisme memandang peran sebagai hasil konstruksi sosial. masyarakat modern membagi produksi dari segi gender dan ruang (sphere) yang disebut sebagai ruang "publik" dan ruang "privat". Dalam hal ini perempuan sengaja diposisikan untuk kepentingan ruang privat, sedangkan laki-laki diberi akses istimewa ke ruang publik.

Ideologi patriaki dituding sebagai biang keladi yang menempatkan laki-laki sebagai pemegang kekuasaan utama dan mendominasi dalam peran kepemimpinan politik, otoritas moral, hak sosial, dan penguasaan materi (Agnia, 2016). Beberapa masyarakat yang bercorak patriarki juga patrilinial yang berarti bahwa materi dan gelar diwariskan kepada keturunan laki-laki. Sistem ini menempatkan keistimewaan pada posisi laki-laki di atas posisi perempuan.

Penelitian terdahulu oleh Wardiah (2006) menekankan urgensi kesetaraan gender dikarenakan wanita dan pria mempunyai hak yang sama dalam membangun bangsa dan negara. Namun studi Jabarullah (2016) justru menujukkan kurangnya peran perempuan dalam pelaksanaan Musrembang Desa sehingga suara perempuan dalam pembangunan desa tidak terwakili. Pada akhirnya kaum perempuan menjadi pelengkap saja, sementara laki-laki selalu mendominasi jabatan atau posisi strategis di pemerintahan desa.

\section{METODE PENELITIAN}

Peneliti melakukan penelitian di Gampong Blang Kecamatan Syamtalira Aron Kabupaten Aceh Utara. Lokasi ini dipilih dikarenakan kurangnya peran perempuan dalam struktur pemerintahan gampong, yang terlihat dari fenomena tidak adanya perempuan yang menjabat sebagai aparatur gampong, sehingga terjadinya disparitas gender. Dalam penelitian ini peneliti 
menggunakan pendekatan kualitatif dengan tipe penelitian deskriptif analisis (Moleong, 2009). Penelitian dengan menggunakan pendekatan kualitatif dimaksudkan untuk memperoleh gambaran yang mendalam dan kompleks terhadap peran perempuan dalam struktur pemerintahan Gampong Blang Kecamatan Syamtalira Aron Kabupaten Aceh Utara. Data primer diperoleh dari informan sebagai bahan penting dalam penelitian (Silalahi, 2009), ditentukan secara purposif. Informan yang dipilih dalam penelitian ini adalah informan yang dianggap paham atas permasalahan penelitian dan dapat mendukung penelitian. Untuk mempermudah mendapatkan data dan informasi yang diperlukan, peneliti menggunakan teknik pengumpulan data dengan menggunakan 3 (tiga) teknik, yaitu teknik pengamatan (observasi), wawancara (interview) dan studi dokumentasi (Sugiyono, 2013). Analisis data yang digunakan dalam memecahkan masalah yang timbul dari penelitian awal sampai selesainya pengumpulan data menggunakan model analisis intreraktif yang menurut Moleong (2009) melalui empat tahapan pengumpulan data, yaitu koleksi data, reduksi data, data display, dan verifikasi.

\section{HASIL DAN PEMBAHASAN}

\section{Faktor Penghambat Peran Aktif Perempuan dalam Struktur Pemerintahan Gampong}

Ada empat tema yang menandai teori ketimpangan gender (Ritzer, 2008). Pertama, lelaki dan wanita diletakkan dalam masyarakat tak hanya secara berbeda, tetapi juga timpang. Kedua, ketimpangan ini berasal dari organisasi masyarakat, bukan dari perbedaan biologis atau kepribadian penting antara lelaki dan wanita. Ketiga, meski manusia secara individual agak berbeda ciri dan tampangnya satu sama lain, namun tidak ada pola perbedaan alamiah signifikan yang membedakan pria dan wanita. Keempat, semua teori ketimpangan menganggap baik itu pria maupun wanita akan menanggapi situasi dan struktur sosial yang makin mengarah ke persamaan derajat (egalitarian) dengan mudah dan secara alamiah. Dengan kata lain, mereka membenarkan adanya peluang untuk mengubah situasi. Dalam teori ketimpangan gender terdapat konsep utama yang digunakan untuk melihat permasalahan gender yaitu feminisme liberal (Musrifah, 2018).

Ketimpangan gender terjadi pula di Gampong Blang, dimana peran perempuan tampaknya sangat rendah. Hal ini dibuktikan dengan tidak terdapatnya jabatan legal dalam struktur pemerintahan gampong yang diemban oleh perempuan. Hal tersebut terlihat dari keterwakilan jumlah anggota aparatur gampong yang tertera dalam struktur Gampong Blang Kecamatan Syamtalira Aron Kabupaten Aceh Utara yang beranggotakan sebagai berikut: 
Tabel 1. Struktur Organisasi Pemerintahan Gampong Blang

Kecamatan Syamtalira Aron Kabupaten Aceh Utara

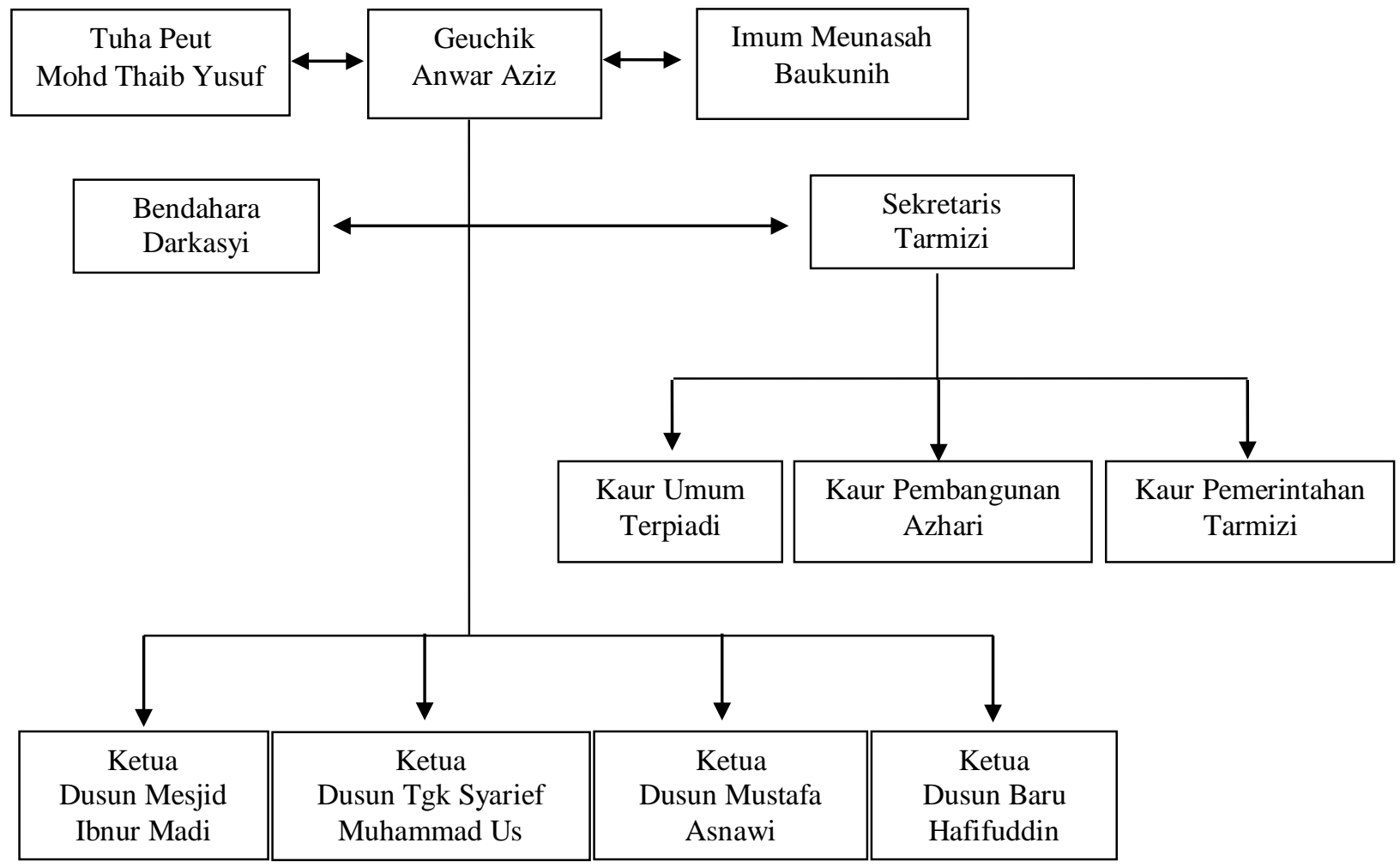

Sumber: RPJM Gampong Blang, 2018

Berdasarkan struktur Gampong Blang terlihat bahwa yang mengisi jabatan di pemerintahan gampong semuanya adalah laki-laki, sedangkan perempuan tidak memiliki ruang untuk berperan aktif dalam pemerintahan gampong. Permasalahan tersebut bukan dikarenakan sedikitnya jumlah kaum perempuan dibandingkan laki-laki. Jumlah penduduk Gampong Blang sendiri terdiri atas 88 laki-laki dan 94 perempuan usia produktif. Begitu pula bila dilihat dari pendidikan, antara kaum laki-laki dan perempuan di Gampong Blang memiliki tingkat pendidikan yang relatif berimbang (RPJM Gampong Blang, 2018).

\section{a. Budaya Patriarki}

Pada umumnya masyarakat Indonesia menganut ideologi patriarki yaitu sebuah sistem sosial yang menempatkan laki-laki sebagai pemegang kekuasaan utama dan mendominasi dalam peran kepemimpinan politik, otoritas moral, hak sosial dan penguasaan materi (Agnia, 2016). Begitu juga dengan masyarakat Gampong Blang, laki-laki lebih mendominasi untuk mengambil keputusan terhadap segala sesuatu yang berhubungan dengan pemerintahan gampong. 
Pemegang kekuasaan dalam pemerintahan Gampong Blang adalah kaum laki-laki dimana peran perempuan dihakimi tidak mampu berperan baik di dalam pemerintahan gampong. Kaum perempuan sendiri di Gampong Blang harus patuh terhadap keputusan laki-laki. Perempuan tidak dapat bertindak atau menjabat suatu posisi dalam struktur pemerintahan gampong jika tidak diberikan izin oleh masyarakat yang dikendalikan kaum laki-laki. Dalam keadaan seperti ini, artinya perempuan tidak memiliki kekuasaan untuk memenuhi kebutuhan dalam rangka pengaktualisasian diri.

Masyarakat Aceh pada umumnya telah mengenal sistem patriaki sejak lama. Sistem ini telah membudaya dalam kehidupan sosial masyarakat terutama di Gampong Blang. Ideologi patriaki ini menjadikan kaum laki-laki memegang kendali di pemerintahan gampong sedangkan kaum perempuan sendiri tidak diberikan kepercayaan untuk mengurus pemerintahan karena dianggap tidak mampu dan lemah (Agnia, 2016). Kaum laki-laki sendiri sebagai pemegang kekuasaan diberikan kepercayaan secara turun-temurun. Setiap laki-laki dianggap mampu dan sesuai dengan urusan pemerintahan gampong. Perempuan menjadi individu yang mau tidak mau harus menerima keputusan laki-laki sebagai pemegang kendali dan kekuasaan dalam struktur pemerintahan gampong.

Laki-laki dipandang sebagai individu yang mampu mengemban tugas-tugas pemerintahan dibandingkan dengan perempuan. Hal itu sebagaimana ungkapan berikut:

"Perempuan tidak diberikan kesempatan... di pemerintahan gampong laki-laki semua yang ikut dan duduk di daftar struktur pemerintahan gampong. Perempuan tidak dapat ikut dalam pemerintahan gampong karena perempuan tidak mendapatkan izin dari masyarakat gampong, khususnya kaum laki-laki.” (Cut Najriati, Gampong Blang, 22/06/2019).

Berdasarkan hasil wawancara di atas dapat dipahami bahwa perempuan harus patuh terhadap keputusan laki-laki. Perempuan tidak dapat bertindak atau menjabat suatu posisi dalam struktur pemerintahan gampong jika tidak diberikan izin oleh masyarakat yang didominasi kaum laki-laki.

Peran perempuan sendiri menjadi syarat mutlak dalam upaya mewujudkan pembangunan yang berkeadilan. Untuk mewujudkan pembangunan yang berkeadilan maka kaum perempuan perlu dilibatkan ke dalam posisi aparatur gampong. Hal ini membuat perempuan mampu mempengaruhi keputusan musyawarah yang dilakukan aparatur gampong selama ini. Persamaan hak dan kewajiban antara laki-laki dan perempuan akan sulit terjadi apabila kaum perempuan tidak memiliki posisi atau jabatan strategis. 
Berdasarkan hasil wawancara Kepala Seksi Kesejahteraan Sosial serta Sekretaris PKK Kecamatan Syamtalira Aron diperoleh keterangan:

"Perempuan tidak punya jabatan di gampong, kalau kader-kader (posyandu) biasa banyak yang berperan, tapi mereka tidak berani bertindak dalam urusan pemerintahan gampong, karena mereka tidak memiliki jabatan. Padahal jabatan sangat berpengaruh agar suara perempuan dapat didengar untuk mendobrak perubahan agar lebih maju." (Nazariyah, Syamtalira Aron, 19/06/2019)

Masyarakat Aceh pada umumnya telah mengenal sistem patriaki sejak lama. Sistem ini telah membudaya dalam kehidupan sosial masyarakat terutama di Gampong Blang. Berdasarkan hasil wawancara dengan salah seorang anggota masyarakat Gampong Blang, ia menyatakan ketidaksetujuannya terhadap eksistensi budaya patriarki sekaligus ketidakberdayaannya menghadapi sistem yang ada saat ini sebagaimana disampaikan:

"Saya tidak setuju dengan kaum laki-laki yang memegang kendali dalam pemerintahan gampong... tapi juga tidak bisa membantah terhadap hal tersebut, karena laki-laki lebih dibutuhkan dan memegang kendali untuk ikut berperan dalam pemerintahan. Kita perempuan ikut sajalah keputusan yang diambil, jadi apa yang bisa kita buat akan kita buat kalau tidak ada, diam di rumah saja.” (Cut Farisa, Gampong Blang, 22/06/2019)

Berdasarkan hasil wawancara dengan Sekretaris dan Kepala Urusan Pemerintahan Gampong Blang, dapat dilihat bagaimana jelmaan budaya patriarki tersebut di dalam alam berpikir masyarakat, terutama sekali aparatur gampong yang didominasi laki-laki. Hal itu berdasarkan penuturan berikut:

"Saya tidak setuju jika ada perempuan dalam pemerintahan gampong, karena yang memimpin itu orang laki-laki, bukan perempuan yang memimpin laki-laki. Perempuan itu, tugas mengikuti keputusan orang laki-laki... dari nenek moyang kitapun yang memimpin itu laki-laki bukan perempuan.” (Tarmizi, Gampong Blang, 29/06/2019)

Inilah alasan yang sulit diubah sehingga menjadi penyebab mengapa peran perempuan dalam kehidupan masyarakat sangat lemah. Rendahnya keterwakilan perempuan dalam pemerintahan gampong kemudian melatarbelakangi lahirnya ketidaksetaraan hak dan kewajiban antara laki-laki dan perempuan. Kaum perempuan dianggap hanya sebagai pelengkap kegiatan dalam kehidupan bermasyarakat.

Berdasarkan hasil wawancara dengan Geucik Gampong Blang Kecamatan Syamtalira Aron, tidak melibatkan perempuan dalam pembangunan gampong didorong oleh hasil keputusan Musrembang Gampong sebagaimana diungkapkan:

"Jika dalam pemerintahan gampong peran aktif perempuan itu tidak ada. Perempuan tidak ikut serta dalam urusan pemerintahan gampong, apalagi dalam bidang pembangunan. Karena, di gampong kita bidang pembangunan dikerjakan oleh kelompok kerja laki-laki 
yang kita pakai. Sebab banyak faktor yang kita lihat jika perempuan ikut dalam pembangunan, apalagi ikut ngurusin urusan gampong. Ini juga berdasarkan dari hasil Musrebang yang kita adakan bahwa perempuan tidak diikutsertakan dalam pemerintahan gampong." (Anwar Aziz, Gampong Blang, 22/12/2018)

Berdasarkan wawancara, hasil Musrembang Gampong justru memarginalkan kaum perempuan dalam proses pembangunan. Hal ini terjadi karena budaya patriarki yang masih kuat mengakar di dalam masyarakat Aceh dan tidak adanya suara yang merepresentasikan perempuan dalam rapat tersebut. Menurut salah seorang akademisi perempuan di Kota Lhokseumawe:

"Pihak masyarakat sendiri menerima budaya patriaki tersebut... kalau kita lihat dari Orde lama sampai masa Reformasi budaya patriaki tersebut masih saja dipegang oleh masyarakat sampai saat ini. Itulah yang menjadi persoalan yang harus kita bahas... bagaimana mengubah budaya patriaki tersebut di masyarakat gampong agar meminimalisir kesenjangan yang telah terjadi.” (Maryam, Bukit Indah, 15/09/2019)

\section{b. Batasan Kehidupan Sosial Masyarakat}

Apabila melihat kehidupan sehari-hari masyarakat Gampong Blang terdapat pembatasan terhadap akses pergaulan kehidupan sosial. Berdasarkan hasil wawancara dengan Ketua PKK Gampong Blang diperoleh informasi:

"Pemikiran masyarakat gampong yang masih kayak zaman dimana perempuan mesti di rumah... kerjaannya di dapur, di kasur, dan sumur. Makanya laki-laki sekarang tidak mau memilih perempuan bukan karena kita bodoh tapi karena tidak diterima posisi atau kedudukan perempuan di pemerintahan...” (Ernita Karmila, Gampong Blang, 24/06/2019)

Menurut informan, pemikiran masyarakat sudah terdoktrin dengan pandangan bahwa kehidupan perempuan hanya untuk mengurusi rumah tangga, seperti memasak, menjaga anakanak, mengurus suami, dan pekerjaan rumah lainnya. Hal itu senada dengan penekanan yang disampaikan oleh Sekretaris dan Kepala Urusan Pemerintahan Gampong Blang berikut:

"Tugas perempuan bukan untuk mengurus pemerintahan gampong... tugas perempuan untuk mengurus rumah tangga, anak-anak di rumah, dan urusan rumah lainnya... perempuan tidak seperti laki-laki yang mampu mengurus persoalan pemerintahan gampong." (Tarmizi, Gampong Blang, 29/06/2019)

Berdasarkan hasil wawancara di atas kaum laki-laki dianggap lebih kuat dan mampu melakukan tugas pemerintahan kapan saja dan dimana saja tidak terbatas ruang dan waktu. Kondisi tersebut sudah membudaya dan tertanam dalam pemikiran masyarakat gampong yang sampai saat ini menjadi penghambat bagi kaum perempuan untuk tumbuh berkembang serta berperan aktif dalam pemerintahan gampong. Kekurangterlibatan perempuan tersebut disampaikan oleh Geucik Gampong Blang sebagaimana petikan wawancara berikut: 
"Perempuan hanya ikut berperan dalam kelompok PKK, kegiatannya hanya apabila ada pesta di masyarakat gampong. Ada juga yang ikut kegiatan Posyandu dalam bidang kesehatan gampong. Sebab kalau kita ikut aturan memang boleh-boleh saja perempuan ikut kegiatan dalam pemerintahan gampong, cuman masyarakat sendiri belum siap karena adatistiadat, juga bertolak belakang terhadap aturan-aturan tersebut." (Anwar Azis, Gampong Blang, 22/06/2019)

Menurut Kepala Seksi Pemberdayaan Masyarakat dan Gampong Kecamatan Syamtalira Aron, dominasi laki-laki mempersempit ruang gerak perempuan dimulai dari wilayah rumah tangga. Hal itu sebagaimana dikatakan:

"Kebanyakan dari suami tidak mengizinkan istrinya berkecimpung dalam pemerintahan gampong karena dianggap tidak pantas, sebab itu urusan para laki-laki." (Sulaiman, Syamtalira Aron, 24/06/2019)

Adat-istiadat dan norma yang berlaku di Gampong Blang sendiri menunjukkan bahwa terdapat pembatasan terhadap akses dan kesempatan perempuan baik dalam pembangunan maupun dalam struktur pemerintahan gampong. Keterbatasan yang diterima oleh kaum perempuan merupakan produk yang dibuat kaum laki-laki dengan menjadikan adat-istiadat sebagai unsur utama produk tersebut. Pembatasan akses dan kesempatan kaum perempuan untuk berperan aktif dalam struktur pemerintahan gampong diperkuat oleh keputusan dan kebijakan bersama yang diambil aparatur gampong. Menanggapi masalah tersebut, informan berikut menyatakan:

"Sebenarnya perempuan itu mampu... Walau sekarang banyak perempuan yang berpendidikan tinggi seperti S-1, S-2, minimal SMA, tetapi cover pemikiran masyarakat tetap memandang bahwa perempuan hanya pantas dan baiknya berada di rumah mengurusi pekerjaan yang ada di rumah" (Maryam, Bukit Indah, 15/09/2019)

Pola pikir seperti ini membuat kesenjangan gender semakin sulit diatasi di dalam masyarakat. Kebiasaan yang telah menjadi nilai-nilai dan aturan kehidupan sehari-hari menjadi sekat pembatas kaum perempuan dalam mengeluarkan aspirasi mereka agar dapat didengar oleh masyarakat.

\section{c. Penolakan Kelompok Masyarakat}

Perempuan menjalankan perannya sesuai dengan hak dan tanggung jawab mereka di dalam kelompok masyarakat. Setiap individu laki-laki dan perempuan terlahir dengan biologis yang sama, terjadinya ketimpangan antara peran laki-laki dan perempuan bukan berasal dari perbedaan fisik dan kepribadian penting antara laki-laki dan perempuan. Namun peran aktif perempuan di dalam struktur pemerintahan gampong terhambat oleh struktur yang mengatur dan memiliki pengaruh 
terhadap pilihan individu dalam kelompok masyarakat. Salah seorang anggota masyarakat Gampong Blang mengatakan:

"Kaum perempuan bukan karena tidak paham atau tidak mengerti tetapi tidak diizinkan oleh masyarakat khususnya orang tua gampong (Tuha Peut). Jadi tidak ada peluang untuk perempuan duduk di dalamnya... sebab banyak orang tua yang tidak setuju kalau perempuan ikut dalam urusan gampong karena urusan gampong adalah urusan laki-laki, perempuan bertugas untuk mengurus rumah tangganya." (Cut Najriati, Gampong Blang, 22/06/2019)

Aspirasi yang disuarakan di atas diamini oleh informan lain yang menjabat sebagai Ketua PKK Gampong Blang. Seingat informan, Gampong Blang pernah membuat terobosan dimana sebagian elemen masyarakat mengajukan perempuan sebagai calon anggota Tuha Peut. Ternyata hal itu menimbulkan resistensi dari anggota Tuha Peut yang menjabat saat itu, sebagaimana diceritakan:

"Ada dua orang perempuan yang dicalonkan untuk menjadi anggota Tuha Peut sebagai perwakilan kalangan perempuan, namun ditolak oleh tokoh-tokoh gampong seperti Tgk. Imum, Tgk. Dayah, dan tokoh agama juga tidak menyetujui perempuan diikutsertakan dengan alasan bukan urusan perempuan tapi urusan laki-laki... laki-laki bisa rapat dimana saja sedangkan perempuan terbatas waktu dan tempat." (Ernita Karmila, Gampong Blang, 22/06/2019)

Keberatan para Tuha Peut didasarkan pada alasan fleksibilitas kaum perempuan dalam bekerja. Perempuan dianggap tidak memiliki kebebasan seperti kaum laki-laki karena mereka berada dalam kendali suaminya. Penolakan yang dilakukan para tokoh gampong sulit ditentang dan diubah, apalagi mereka menguasai struktur signifikansi dengan pengetahuan agama yang kuat. Salah seorang Tuha Peut Gampong Blang menyampaikan:

"Perempuan itu baiknya berada di rumah saja, mengurusi persoalan seputar keluarganya, bukan yang keluar dengan sengaja untuk mengurusi urusan politik pemerintahan gampong. Pemerintahan gampong biarkan menjadi urusan bapak-bapak di gampong, tidak baik jika perempuan ikut bergabung mengingat keterbatasan perempuan yang tidak mungkin bisa duduk rapat di bale-bale pengajian dan harus bergabung dengan laki-laki hingga larut malam.” (Mohd Thaib Yusuf, Gampong Blang, 29/06/2019)

Pandangan ini disayangkan oleh salah seorang akademisi perempuan. Informan menyatakan:

"Perempuan sebenarnya mempunyai 30\% (tiga puluh persen) peluang dalam pemerintahan, dimana hal tersebut telah diatur oleh undang-undang pemerintahan, minimal satu atau dua orang perempuan berada di pemerintahan untuk keterwakilan suara kaum perempuan dalam pemerintahan. Namun hal tersebut yang minim terjadi karena tidak adanya akses peluang untuk perempuan sendiri... Tuha Peut anggotanya tidak boleh genap yaitu lima orang sekurang-kurangnya, seharusnya di dalam lima orang tersebut empat orang kaum laki-laki dan satu orang kaum perempuan untuk mewakili suara perempuan di gampong. Tetapi hal 
tersebut masih ditolak oleh masyarakat seperti petua-petua gampong yang tidak menerima peran perempuan di dalam keanggotaan Tuha Peut." (Maryam, Bukit Indah, 15/09/2019)

d. Kebudayaan

Masyarakat Gampong Blang membentuk pola berpikir, merasakan, dan bertindak berdasarkan kebudayaan atau kebiasaan yang sudah berlaku secara turun-temurun. Kebiasaan tersebut tidak membenarkan perempuan turut serta di dalam struktur pemerintahan gampong. Menurut Geucik Gampong Blang, kebudayaan Aceh melarang perempuan mencampuri urusan politik gampong karena berbagai pertimbangan sebagaimana pernyataan beliau:

"Menurut saya salah satu faktor utama ya budaya dan adat-istiadat yang ada di kita sekarang, dan ada juga tidak diizinkan suami. Karena belum ada sinyal untuk perempuan ikut terlibat walaupun peraturan negara tidak menghalangi." (Anwar Azis, Gampong Blang, 22/06/2019)

Bila di Gampong Blang peran perempuan nyaris tenggelam, tidak demikian halnya di tingkat kecamatan. Berdasarkan hasil wawancara dengan Kepala Seksi Pemberdayaan Masyarakat dan Gampong Kecamatan Syamtalira Aron, sudah banyak perempuan terlibat dalam struktur

pemerintahan di Kecamatan Syamtalira Aron. Begitu pula di struktur pemerintahan gampong, pihak kecamatan tidak pernah mempermasalahkan peran serta perempuan, malah sebaliknya mendukung upaya ke arah itu. Menurut informan:

"Kalau kecamatan tidak membatasi peran perempuan dalam struktur pemerintahan gampong. Cuma mungkin karena adat-istiadat yang berbeda menjadi daya ikat yang akhirnya membatasi ruang gerak perempuan.” (Sulaiman, Syamtalira Aron, 24/06/2019)

Tata kelakuan tersebut memberikan batas-batas pada perilaku individu agar berbuat sesuai dengan keadaan dan kondisi yang diharapkan terjadi dalam masyarakat. Apabila melihat pernyataan-pernyataan di atas, masyarakat Gampong Blang juga menjadikan tata kelakuan sebagai pembatasan-pembatasan perilaku anggotanya untuk bertindak dan berperilaku sesuai nilai dan norma yang dianut masyarakat. Kaum perempuan dianggap tidak baik untuk ikut serta dan berperan aktif dalam pemerintahan gampong dikarenakan legitimasi budaya yang menganggap bahwa hal tersebut tidak pantas untuk dilakukan oleh kaum perempuan seperti berkumpul dalam sebuah forum dengan laki-laki, dan sebagainya.

\section{Upaya Mendukung Peran Aktif Perempuan dalam Struktur Pemerintahan Gampong}

Sosialisasi adalah proses penanaman atau transfer kebiasaan atau nilai dan aturan dari satu generasi ke generasi lainnya dalam sebuah kelompok atau masyarakat. Menurut Berger \& 
Luckman (1990) sosialisasi dibagi menjadi dua, yaitu sosilaisasi primer dan sosialisasi sekunder. Sosialisasi primer sebagai sosialisasi pertama yang dijalani individu semasa kecil dengan belajar menjadi anggota masyarakat (keluarga). Sosialisasi sekunder adalah suatu proses sosialisasi lanjutan setelah sosialisasi primer yang memperkenalkan individu ke dalam kelompok tertentu dalam masyarakat. Dalam hal ini yang dilakukan kecamatan adalah sosialisasi sekunder. Pihak kecamatan memberikan pemahaman dan pembelajaran kepada masyarakat khususnya perempuan tentang aturan-aturan yang mengharuskan perenpuan untuk ikut berperan aktif dalam struktur pemerintahan gampong. Berdasarkan hasil wawancara dengan Kepala Seksi Pemberdayaan Masyarakat dan Gampong Kecamatan Syamtalira Aron diperoleh keterangan:

"Kami, kecamatan menghimbau agar kaum perempuan lebih aktif karena kita lihat banyak generasi muda perempuan yang memiliki potensi yang baik. Namun kembali lagi ke aturan masyarakat gampong yang menerima/menolak peran aktif perempuan di struktur pemerintahan gampong." (Sulaiman, Syamtalira Aron, 24/06/2019)

Himbauan pihak kecamatan tentunya dengan mensosialisasikan aturan-aturan mengenai keharusan peran aktif perempuan dalam pemerintahan gampong seperti Undang-Undang Nomor 6 Tahun 2014 tentang Desa yang mengharuskan partisipasi dan peran perempuan dalam pemerintahan gampong dan Qanun Aceh Nomor 6 Tahun 2009 tentang Pemberdayaan dan Perlindungan Perempuan agar aspirasi perempuan dapat tersalurkan dengan baik. Hal itu dibenarkan oleh informan berikut yang menjabat sebagai Sekretaris PKK Kecamatan Syamtalira Aron:

"Dari pihak kecamatan beberapa kali diadakan penyuluhan atau sosialisasi, salah satunya dengan tema "Emansipasi Wanita" dengan tujuan untuk mengubah pola pikir masyarakat terhadap perempuan yang tidak hanya bergelut dengan urusan rumah saja, tetapi perempuan juga dapat ikut berperan aktif dalam pemerintahan gampong. Dengan kegiatan tersebut diharapkan setiap gampong dapat diberdayakan para perempuannya." (Nazariyah, Syamtalira Aron, 22/12/2018)

Kebiasaan dan pola pikir masyarakat gampong memang sangat sulit diubah jika tidak ada dukungan moral dari pemerintah gampong sendiri. Berdasarkan hasil wawancara dengan salah seorang anggota masyarakat Gampong Blang, ia menyuarakan harapannya:

“... untuk pemerintahan gampong atau masyarakat sebaiknya dapat merubah pola pikirnya terhadap kaum perempuan sehingga dapat menerima kontribusi dan peran aktif dari perempuan untuk ikut dalam pemerintahan gampong... sayang jika perempuan harus berada di rumah saja" (Cut Farisa, Gampong Blang, 22/06/2019)

Menurut informan permasalahan yang terjadi saat ini disebabkan pola pikir yang tidak terbuka sehingga terjadinya sikap penolakan terhadap kontribusi perempuan untuk ikut berperan 
aktif dalam pemerintahan. Perempuan terasing dari kehidupan sosial yang lebih luas, tidak dapat bebas berpendapat, bertindak, dan berkontribusi seperti yang dilakukan kaum laki-laki. Menanggapi hal ini, salah seorang akademisi perempuan menyatakan:

“... kesenjangan gender... seharusnya ada pergerakan dari pemerintah, setidaknya memulai pada satu gampong untuk melakukan pendampingan di masyarakat untuk menjalankan pelatihan, pengembangan diri... sehingga wacana pikir masyarakat dapat diubah dan dapat bergerak maju menerima perubahan terhadap peran serta kaum perempuan di pemerintahan gampong." (Maryam, Bukit Indah, 15/09/2019)

Keberhasilan yang diperoleh dengan berbagai program yang dibuat akan membawa dampak yang baik, yang dapat membawa perubahan bagi kemajuan kehidupan kaum perempuan, dimana dengan wacana pikir yang maju dan berkembang maka perempuan dapat diberikan peluang dan akses untuk berada di ruang publik, maka suara dan aspirasi perempuan akan dapat disalurkan sesuai dengan kebutuhan kaum perempuan sendiri.

\section{Pembahasan}

Posisi kaum perempuan di dalam pemerintahan gampong sangatlah menentukan kekuasaan dan status perempuaan itu sendiri, dimana peran aktif perempuan dapat mengubah pandangan kaum perempuan di hadapan kaum laki-laki. Keterlibatan memungkinkan kaum perempuan dapat menyalurkan aspirasi dan kreatifitas demi kemajuan gampong. Peran perempuan dalam pemerintahan gampong sendiri sangatlah dibutuhkan baik dalam proses perumusan maupun pelaksanaan kebijakan di tingkat gampong. Namun dikarenakan tidak adanya kekuasaan yang dipegang oleh kaum perempuan maka dari situlah kaum perempuan tidak dapat ikut berperan aktif dan tidak mempunyai kedudukan di struktur pemerintahan gampong.

Disebabkan pemegang kekuasaan atau kepemimpinan adalah dari kaum laki-laki, seluruh masyarakat menerima dan berpegang teguh dengan ideologi ini. Apabila kita lihat secara lebih mendalam, posisi perempuan dalam kehidupan sosial masyarakat menunjukkan bahwa posisi lakilaki di atas posisi perempuan. Perempuan hakekatnya berada di bawah kaum laki-laki sehingga ruang gerak perempuan terbatas oleh pandangan yang sudah membudaya di kalangan masyarakat gampong.

Hakekat yang menjadikan kaum perempuan berada di bawah kaum laki-laki dianggap menjadi masalah bagi sebagian masyarakat gampong dimana hal tersebut sudah tertanam kuat di kalangan masyarakat. Pemberontakan dari sebagian perempuan adalah suatu bentuk aspirasi yang disuarakan. Namun sangat disayangkan karena faktor ideologi yang tertanam sejak turun temurun maka tidak tampak kemauan politik elite gampong untuk mengubah situasi. 
Ideologi patriarki tersebut menjadi salah satu struktur terpenting di dalam masyarakat gampong, karena terus dijunjung tinggi dan dianggap tidak merugikan kaum perempuan. Pada hakekatnya kaum perempuan sangat merasa dirugikan dikarenakan kaum perempuan tidak dapat menentang apa yang telah menjadi kesepakatan kaum laki-laki. Hak yang dimiliki kaum perempuan untuk berperan aktif di pemerintahan gampong hanya diwakili oleh kaum laki-laki, sedangkan kaum perempuan hanya dapat menerima apa yang sudah menjadi kesepakatan bersama. Dengan demikian suara dari kaum perempuan tetap saja tidak tersalurkan karena yang lebih memahami kebutuhan dan keinginan kaum perempuan adalah perempuan itu sendiri.

Masyarakat sendiri seharusnya mengetahui pentingnya perempuan dalam pemerintahan gampong yang telah tertera di prosedur dan undang-undang desa itu sendiri. Namun yang kita ketemui di Gampong Blang tidak ada satu orangpun dari kaum perempuan yang ikut berperan aktif dan namanya tertera di struktur pemerintahan gampong. Faktanya kaum perempuan juga sangat dibutuhkan dalam pembangunan gampong. Kaum laki-laki dan perempuan sejatinya dapat menjadi tim yang solid dalam memajukan pembangunan gampong, bukan malah mengenyampingkan peran kaum perempuan yang dianggap sebagai pelengkap saja.

Apabila melihat kehidupan sehari-hari masyarakat gampong Blang terdapat pembatasan terhadap akses pergaulan kehidupan sosial. Pembatasan akses pergaulan kehidupan sosial juga diperketat dengan penekanan atas cara bersikap dan berpikir sesuai keinginan masyarakat. Keadaan tersebut adalah sebuah doktrin yang terus ditanamkan pada setiap individu baik perempuan atau laki-laki sehingga terciptanya ruang-ruang yang berjarak antara aktivitas kehidupan laki-laki dan aktivitas kehidupan perempuan.

Ruang-ruang pembatas antara hak dan kewajiban kaum laki-laki dan kaum perempuan membuat kesenjangan yang dapat merugikan kaum perempuan. Pengotakan ini membuat aspirasi perempuan tidak dapat sepenuhnya disalurkan. Pemikiran masyarakat sudah terdoktrin agar kehidupan perempuan hanya untuk mengurusi rumah tangga, seperti memasak, menjaga anakanak, mengurus suami, dan pekerjaan rumah lainnya. Hal ini yang membatasi kehidupan perempuan untuk dapat mengaktualisasikan diri mereka pada bidang kehidupan yang lebih luas atau memperoleh akses ke ruang publik. Maka bisa dikatakan kaum perempuan kurang diperhatikan di ruang lingkup gampong. Perhatian pemerintahan gampong terfokus pada kinerja kaum laki-laki yang dianggap lebih kuat dan mampu mengurus pemerintahan gampong sehingga timbulnya pembatasan akses terhadap perempuan untuk dapat berperan aktif dalam struktur pemerintahan gampong. Kehidupan sosial masyarakat sangat menentukan posisi seseorang di 
dalam masyarakat, dimana kebiasaan masyarakat menjadi batasan untuk kaum perempuan untuk tidak dapat dengan leluasa ikut berperan di dalam kebijakan pemerintahan.

Sesungguhnya tidak terdapat perbedaan yang signifikan antara kemampuan laki-laki dan perempuan. Setiap individu baik laki-laki ataupun perempuan terlahir dengan biologis yang sama. Terjadinya ketimpangan antara peran laki-laki dan perempuan bukan berasal dari perbedaan fisik dan kepribadian antara laki-laki dan perempuan. Namun peran aktif perempuan di dalam struktur pemerintahan gampong terhambat oleh lembaga yang mengatur dan memiliki pengaruh terhadap pilihan individu dalam kelompok masyarakat.

Hambatan yang berasal dari lembaga gampong membawa pengaruh besar terhadap kaum perempuan. Sejumlah kelompok masyarakat menolak ikut sertanya perempuan untuk berperan aktif dalam pemerintahan gampong. Penolakan tersebut banyak mempengaruhi masyarakat gampong yang dikarenakan kekuasaan sekelompok elite masyarakat yang didengar oleh masyarakat lainnya untuk menolak peran aktif perempuan dalam pemerintahan gampong. Penolakan tersebut dilakukan karena sebab pola pikir yang menilai ketidakpantasan kaum perempuan untuk duduk dan memiliki jabatan di pemerintahan gampong, sehingga ruang lingkup peran perempuan sebatas untuk mendukung keputusan dan perencanaan yang telah dibuat oleh kaum laki-laki dan perempuan sendiri hanya menjadi pelengkap untuk kemajuan gampong.

Secara intelektual kaum perempuan di Gampong Blang mengaku telah mengerti dan memahami tugas dan fungsi struktur pemerintahan gampong. Namun para perempuan yang telah memiliki kapasitas intelektual yang cukup untuk memiliki posisi dalam struktur pemerintahan gampong tetap saja tidak diberikan peluang atau kesempatan untuk berkontribusi atau berperan aktif dalam pemerintahan gampong. Kebijakan untuk mempersempit peluang dan kesempatan berkontribusi atau berperan aktif dalam pemerintahan gampong dipengaruhi oleh keputusan orang tua gampong (tuha peut) sebagai lembaga resmi pemerintahan gampong dan menjadi penasehat untuk geucik gampong. Tidak adanya dukungan moral dari pemerintahan gampong yang mendorong perempuan untuk diikutsertakan dalam struktur pemerintahan gampong membuat segalanya menjadi lebih sulit bagi kaum perempuan.

Masyarakat yang terdiri dari individu-individu menjadi sebuah kelompok tertentu yang memiliki kebudayaan sendiri. Masyarakat Gampong Blang dalam menilai sebuah tindakan dan sikap individu merujuk kepada nilai dan norma yang berlaku. Masyarakat membentuk pola-pola berpikir, merasakan, dan bertindak setiap anggota masyarakatnya berdasarkan kebudayaan atau kebiasaan yang sudah berlaku secara turun-temurun. Salah satu faktor utama penghambat peran aktif perempuan dalam struktur pemerintahan gampong disebabkan karena budaya dan adat203 | Jurnal Ilmu Sosial dan Ilmu Politik Malikussaleh (JSPM) Volume 1 Nomor 2 Tahun 2020 
istiadat. Adat-istiadat yang dianut masyarakat Gampong Blang mengatur perempuan agar tidak ikut terlibat dalam pemerintahan gampong. Berbagai alasan dijadikan sebagai landasan agar perempuan dipersempit ruang geraknya untuk berperan aktif dalam struktur pemerintahan gampong. Misalnya karena rapat aparatur gampong sering diadakan pada malam hari, tidak diizinkan oleh suami, kondisi perempuan tidak sekuat laki-laki, dan berbagai dalih lainnya. Hal tersebut menandakan bahwa aturan-aturan pelarangan terhadap peran aktif perempuan di dalam struktur pemerintahan gampong berdasarkan kebudayaan dan adat-istiadat yang berlaku.

Adat istiadat yang dipegang teguh masyarakat gampong menjadikan perempuan untuk patuh dan ikut dalam setiap keputusan yang melarang ruang gerak perempuan agar tidak dapat ikut berperan. Ruang gerak kaum perempuan sebatas kegiatan rumah yang turun temurun wajib dilakukan dan dikerjakan oleh perempuan. Adat istiadat tersebut sulit untuk dihilangkan di tengah masyarakat Gampong Blang karena adat-istiadat menjadi kendala utama untuk perempuan ikut berperan aktif dalam pemerintahan gampong.

Sosialisasi adalah proses penanaman atau transfer kebiasaan atau nilai dan aturan dari satu generasi ke generasi lainnya dalam sebuah kelompok atau masyarakat. Dari penelitian ini melihat faktor yang yang menjadi penyebab sulitnya perempuan untuk berperan aktif dalam struktur pemerintahan gampong sehingga timbul upaya untuk menghilangkan kesenjangan yang terjadi di masyarakat gampong untuk dapat menerima peran perempuan dalam struktur pemerintahan gampong.

Pihak kecamatan telah melakukan berbagai upaya untuk mengubah pola pikir masyarakat terhadap peranan perempuan dalam struktur pemerintahan gampong. Pihak kecamatan memberikan pemahaman dan pembelajaran kepada masyarakat khususnya perempuan tentang aturan-aturan yang mengharuskan perempuan untuk ikut berperan aktif dalam struktur pemerintahan gampong. Pihak kecamatan juga telah menghimbau seluruh kaum perempuan di kecamatan Syamtalira Aron khususnya Gampong Blang agar kaum perempuan aktif dalam struktur pemerintahan gampong. Himbauan tersebut tentunya dengan mensosialisasikan aturan-aturan mengenai keharusan peran aktif perempuan dalam pemerintahan gampong.

Dalam realitanya upaya yang dilakukan pihak kecamatan melalui pemerintahan gampong terhadap perubahan pola pikir masyarakat yang mengenyampingkan posisi dan kedudukan kaum perempuan di pemerintahan gampong masih saja belum efektif dan dapat dikatakan tidak berhasil. Realitasnya terlihat bahwa hak dan peran aktif perempuan masih tidak ada di dalam struktur pemerintahan gampong. Masyarakat gampong masih menganggap bahwa perempuan tetap tidak pantas berada di pemerintahan gampong dan tidak sanggup mengemban jabatan di dalam 
pemerintahan gampong sehingga urusan pemerintahan gampong sepenuhnya dipegang dan dikuasai oleh kaum laki-laki.

Dampak dari kesenjangan tersebutlah yang membuat masyarakat sulit untuk maju dan berkembang untuk memandirikan diri sendiri dan gampong. Masyarakat yang masih memegang teguh ideologi, budaya adat istiadat dan kebiasaan pola pikir masyarakat gampong tersebutlah yang membuat sulitnya menerima perubahan-perubahan yang dilakukan demi kemajuan, sehingga upaya yang berulang kali dilakukan juga tidak dapat mengurangi kesenjangan yang terjadi di masyarakat. Posisi dan kedudukan kaum perempuan pun tetap saja dianggap tidak terlalu penting karena merasa semua masalah dapat diatasi oleh kaum laki-laki.

Keterlibatan perempuan dalam pembangunan sangat penting dan mendesak untuk diwujudkan. Hal itu membuat kaum perempuan mampu mengembangkan kemandirian dan keterampilan diri, serta mampu memapankan perekonomian diri sendiri. Dampak baik tersebut juga dapat mendorong perkembangan dan kemajuan gampong di masa mendatang.

\section{KESIMPULAN}

Berdasarkan hasil penelitian yang didapatkan di lapangan, maka yang menjadi kesimpulan dalam penelitian ini adalah:

1. Peran aktif perempuan sangat minim disebabkan masih adanya keterbatasan ruang gerak bagi kaum perempuan untuk ikut berperan aktif dalam struktur pemerintahan Gampong Blang. Hal ini didorong oleh tidak adanya kekuasaan, kuatnya batasan kehidupan sosial masyarakat, penolakan kelompok masyarakat, ideologi patriaki (penekanan peran pada laki-laki), serta yang menjadi faktor mendasar adalah faktor budaya masyarakat Gampong Blang.

2. Kecamatan berupaya meningkatkan peran aktif kaum perempuan dengan melakukan sosialisasi dan penyuluhan, serta memberikan pemahaman dan pencerahan kepada masyarakat khususnya kaum perempuan tentang pentingnya perempuan untuk ikut berperan aktif dalam struktur pemerintahan gampong. Program tersebut diharapkan dapat mengubah pola pikir masyarakat terhadap peran perempuan dalam pemerintahan gampong untuk bisa menerima dan memberi akses bagi kaum perempuan agar dapat berperan aktif di dalam struktur pemerintahan gampong. 


\section{DAFTAR PUSTAKA}

Agnia, D. (2016). Kajian Kritis Budaya Patriarkhisme dalam Agama dan Keadilan Perempuan (Studi Ketentuan Poligami dalam UU No. 1 Tahun 1974). Tesis. Program Pascasarjana Universitas Negeri Lampung.

Berger, P. L. \& Luckmann, T. (1990). Tafsir Sosial atas Kenyataan: Risalah tentang Sosiologi Pengetahuan. LP3ES.

Berry, D. (2003). The Principle of Sociology. PT RajaGrafindo Persada.

Jabarullah (2016). Partisipasi Perempuan dalam Musyawarah Perencanaan Pembangunan (Studi di Gampong Meunasah Blang Kandang Kota Lhokseumawe). Skripsi. FISIP Universitas Malikussaleh.

Fakih, M. (2004). Analisis Gender dan Transformasi Sosial. Pustaka Pelajar.

Fitri, L. A. (2009). Studi Feminis: Kritik atas Paradigma Feminisme Liberal. UIN Sunan Ampel.

Moekijat (2001). Peranan Kepala Desa dalam Masyarakat. PT. Remaja Rosdakarya.

Moleong, L. J. (2009). Metode Penelitian Kualitatif. PT. Remaja Rosdakarya.

Musrifah, M. (2018). Feminisme Liberal dalam Novel Sepenggal Bulan Untukmu Karya Zhaenal Fanani. Lingua Franca: Jurnal Bahasa, Sastra, dan Pengajarannya, 2(1).

Nasution, Z. (2002). Komunikasi Pembangunan: Pengenalan Teori dan Penerapannya. PT. RajaGrafindo Persada.

Qanun Aceh Nomor 6 Tahun 2009 tentang Pemberdayaan dan Perlindungan Perempuan.

Rencana Pembangunan Jangka Menengah Gampong (RPJMG) Blang.

Ritzer, G. (2008). Teori Sosiologi Modern. Kencana.

Silalahi, U. (2009). Metode Penelitian Sosial. PT. Refika Aditama.

Soekanto, S. (2010). Sosiologi Suatu Pengantar. Rajawali Pers.

Sugiyono (2013). Metode Penelitian Kuantitatif Kualitatif dan $R \& D$. Alfabeta.

Sunarto, K. (2004). Pengantar Sosiologi (Edisi Revisi). Lembaga Penerbit Fakultas Ekonomi Universitas Indonesia.

Undang-Undang Dasar Negara Republik Indonesia Tahun 1945.

Undang-Undang Nomor 6 Tahun 2014 tentang Desa.

Wardiah (2006). Keterlibatan Wanita dalam Pembangunan Gampong (Studi di Kemukiman Balee Labang, Kecamatan Jeumpa, Kabupaten Bireuen). Skripsi. FISIP Universitas Malikussaleh.

206 | Jurnal Ilmu Sosial dan Ilmu Politik Malikussaleh (JSPM) Volume 1 Nomor 2 Tahun 2020 